\title{
The Effects of Progesterone on Hypoxic Ischemic Injuries in the Cornu Ammonis (CA) Region of the Hippocampus of Neonatal Rats
}

\author{
Efectos de la Progesterona en Lesiones por Hipoxia Isquémica en la \\ Región Cornu Ammonis (CA) del Hipocampo en Ratas Neonatas
}

Aaijaz Ahmed Khan*; Norhida Binti Ramli** \& Zulizhar Mohd. Ismail*

KHAN, A. A.; RAMLI, N. B. \& ISMAIL, Z. M. The effects of progesterone on hypoxic ischemic injuries in the cornu ammonis (CA) region of the hippocampus of neonatal rats. Int. J. Morphol., 33(3):962-970, 2015.

SUMMARY: Hypoxia-ischemia (HI) is a major cause of brain damage in the newborn. Several studies elicited the neuroprotective effects of progesterone in adult rats but there is very little literature available on neonatal rats. Therefore the present study is undertaken to see the effect of progesterone in hypoxic ischemic brain injury in neonatal rats, using an established neonatal HI rat pup model. Sevenday-old rat pups were subjected to right common carotid artery ligation and then 60 minutes hypoxia. The first dose of progesterone to treatment group was administered by peritoneal injection $(4 \mathrm{mg} / \mathrm{kg})$, after 10 minutes of exposure and subsequent doses were given by subcutaneous injection at $6 \mathrm{~h}, 24 \mathrm{~h}$ and $48 \mathrm{~h}$ intervals. Control group was also exposed to $\mathrm{HI}$ and was given only the vehicle (peanut oil) through the same route and intervals as that of treatment group. After $96 \mathrm{~h}$, the pups were perfused with $10 \%$ formalin and brains were sampled and stained with toluidine blue. Cells density and number of pyramidal cells of the hippocampal Cornu Ammonis (CA) regions were examined by stereological methods. The histomorphometric assessment of the effects of progesterone showed minimal but no significant protective value in the volume, cells density and total number of pyramidal cells of hippocampal CA region of the treatment and control groups ( $p>0.05$ ) after HI. Our results concluded that $4 \mathrm{mg} / \mathrm{kg}$ of PROG had no significant neuroprotective effect in HI model of the neonatal rat's hippocampus.

KEY WORDS: Cornu Ammonis; Hippocampus; Hypoxia; Ischemia; Neonatal rats; Neuroprotective; Progestrone; Pyramidal cell.

\section{INTRODUCTION}

Birth asphyxia occurs when there is inadequate oxygen supply to the neonate just before, during and after birth. Hypoxic ischemic encephalopathy is the outcome of severe birth asphyxia which subsequently may lead to permanent irreversible neurological damage. Current protocols for managing this problem are mostly supportive and treatment is carried out only for its complications. Several neuroprotective agents are still under studies and most of the studies were done on animal.

Progesterone is a steroid hormone with known effects on woman reproductive system. Recent advances have revealed its neuroprotective effect against brain injury in adult rats (Jiang et al., 1996, Chen et al., 1999; Shear et al.,
2002; Sayeed et al., 2007; Cai et al., 2008). In these studies, progesterone was proved to reduce the cortical infarct volume, brain edema and even functional deficit in the rats with induced brain injury. One particular clinical trial on human has actually proven that there is a significant protective effect of progesterone in traumatic adult brain injury (Wright et al., 2007).

Despite the new current technology in medical field, birth asphyxia is still one of the leading causes of neurodevelopmental abnormalities and permanent handicap (Volpe, 2008). Thirty percent of them develop seizures and twenty percent of them with moderate encephalopathy develop cerebral palsy (Volpe). The mortality and morbidity

\footnotetext{
* Department of Anatomy, School of Medical Sciences, Universiti Sains, Penang, Malaysia

** University Malaysia Sarawak, Sarawak, Malaysia.

The study was carried in Department of Anatomy, PPSP, USM, Kempus Kesihatan, Kubang Kerian- 16150, KotaBharu, Kelantan, Malaysia in the year 2010-11 with the help of short term grant (304/PPSP/61310033) from Universiti Sains Malaysia.
} 
among neonates could be reduced significantly if there is a drug with the capacity to prevent the neuronal death due to hypoxia.

Most of the previous studies on the neuroprotective effects of progesterone were done in adult rats (Jiang et al.; Shear et al.; Sayeed et al.; Cai et al.). There is yet no experiment being done in investigating the neuroprotective effects of progesterone in an immature rat brain injury. Therefore the aim of this study was to investigate the neuroprotective effect of progesterone on hypoxic ischemic injury in developing or immature rat brain. In particular, this was determined quantitatively by the total number of surviving pyramidal cells in the hippocampus. The findings obtained are useful in giving new information and understanding regarding possible progesterone potential as medication in treating neonates with brain injury.

\section{MATERIAL AND METHODO}

A total number of 48 male Sprague Dawley rat pups were used in this study. The study was conducted on their postnatal day 7 of life (PND7) (Chen et al.; Moralí et al. 2005; Cai et al.). PND7 was chosen because at this stage, the development of the rat brain is histologically similar to a 32- to 34-week gestation of human fetus or newborn infant where cerebral cortical neuronal layering is complete, the germinal matrix is involuting and white matter has undergone little myelinations (Vannucci et al., 1999).

The pups were divided randomly into three groups, the sham operated, treatment and control groups. The pups $(n=16)$ in sham group were exposed to anaesthetic procedure and surgery, skin incision with some soft tissue removal, without the carotid artery ligation and hypoxic induction procedure (Cai et al., 2009). The pups ( $\mathrm{n}=16)$ in treatment group were exposed to ischemic and hypoxic induction followed by progesterone (4-Pregnene-3, 20-dione) (Sigma Aldrich, USA) treatment at different intervals. The concentration of progesterone given was $4 \mathrm{mg} / \mathrm{kg}$ of body weight. Progesterone was administered in the form of injection at 10 minutes, $6 \mathrm{~h}, 24 \mathrm{~h}$ and $48 \mathrm{~h}$ after the hypoxic induction. The pups $(n=16)$ in control group were also exposed to the hypoxic-ischemic procedure and were injected with only peanut oil. The time and methods of administration were similar with that of treatment group.

The methods used in this study were based on the Levine preparation of hypoxia-ischemia in adult rats (Vannucci \& Vannucciand, 1997). There were two parts in hypoxic ischemic induction. For inducing ischemia to the brain, blood supply to the right hemisphere of cerebrum was cut off permanently by ligating the right common carotid artery. This is followed by hypoxic induction which was by exposing the pups to hypoxic environment for 60 minutes. The hypoxic environment was induced by giving free flow of $8 \%$ oxygen in $92 \%$ nitrogen balance into an airtight chamber (measuring about $20 \mathrm{~cm}$ by $50 \mathrm{~cm}$ ) which has two holes that allow the gases to pass through. Ten minutes after the hypoxic induction, the first dose of progesterone was administered intraperitoneally to the treatment group and the first dose of peanut oil was administered intraperitoneally to the control group for rapid absorption. For gradual absorption, second, third and fourth injections were given via subcutaneous route at 6,24 and 48 hours respectively after the hypoxic induction. At PND11 of hypoxic-ischemic induction, all the pups were euthanized and perfused with $10 \%$ formalin solution. For tissue preparation, the cerebrums were separated from the brainstem and cerebellum. The cerebrums were processed using standard paraffin tissue processing and stained with Toluidine blue in order to stain the pyramidal cells of the hippocampus. The tissue blocks were cut horizontally in serial sections at $4 \mu \mathrm{m}$ thickness using rotator microtome (Leica, UK). The first section that cut through the hippocampal tissue was numbered as the first section and all subsequent sections were numbered sequentially (Miki et al. 2000a, 2000b). A number between 1 and 80 was randomly selected (Fig. 1). Every 80th section was selected for stereological analysis until the entire hippocampal tissues were exhaustively sectioned. The averages of 10 sections were sampled from each hippocampus.

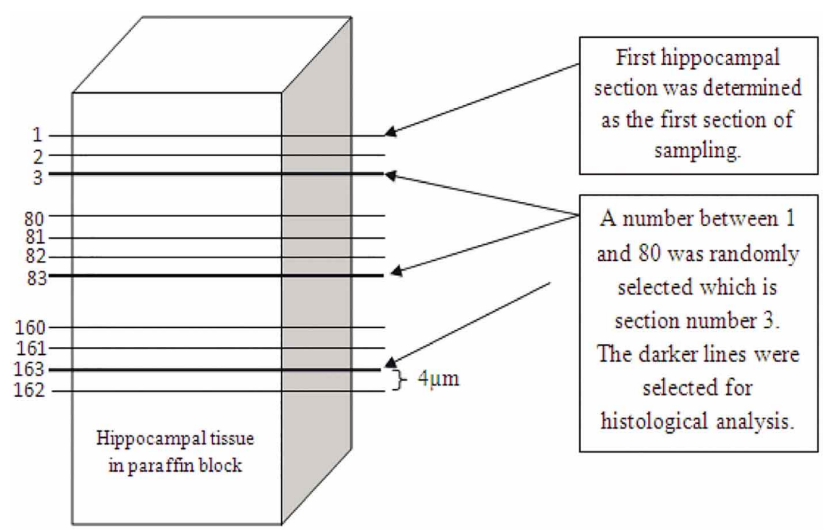

Fig. 1. A schematic diagram of hippocampal tissue sampling procedure.

Stereological technique: Estimation of volume of hippocampal cornu ammonis pyramidal cells layer. The volume of the various subregions of the cornu ammonis (CA) of the hippocampus was determined using the Cavalieri principle (Gundersen \& Jensen, 1987). For this, one section 
from each hippocampus was in turn, viewed at $2 \mathrm{x}$ magnification under a light microscope which is connected to a computer with Pro Plus image analyser (Media Cybernatic, USA). Each image was superimposed at random, with a grid mask having a regular array of test points $5 \mathrm{~mm}$ apart. Each point represented an area (u) of $0.6939 \mathrm{~mm}^{2}$ in the section plane. The captured image of hippocampus with its grid mask was then printed with a laser printer (Fig. 2). The total number (P) of test points falling on each of the CA1, CA2 and CA3 subregions in the sampled sections from any given hippocampus was counted (Fig. 2). The average number of points counted over the CA1 + CA2 + CA3 within the sections was approximately 130 for each pup and these numbers were sufficient to provide reasonable precision and accuracy of the estimates (Gundersen \& Jensen). Points that fell on the hippocampal pyramidal layer were counted as test point. These counts for any given subdivision are related to the volume $(\mathrm{V})$ of the subdivision by the following relationship:

$$
\mathrm{V}=\mathrm{PutN} / \mathrm{n}
$$

Where $\mathrm{N}$ is the total number of serial sections through the hippocampus, $\mathrm{n}$ is the number of sections sampled for the point counting procedure and $t$ is the mean thickness of the serial sections.

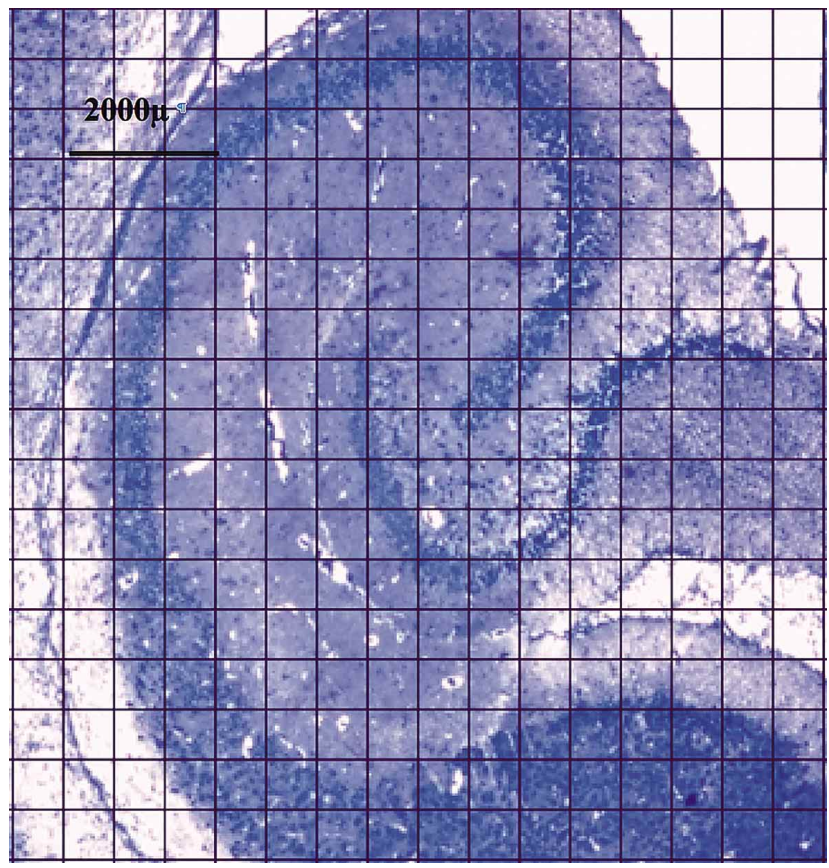

Fig. 2. Photomicrograph of a $4 \mu \mathrm{m}$ section of hippocampal formation in Toluidine blue stained at $2 \mathrm{x}$ objective magnification, superimposed on a randomly positioned grid mask with a regular array of test point.
Estimation of hippocampal CA region pyramidal cell density. The numerical densities of the pyramidal cells in the CA subregions of the hippocampus were estimated using the dissector method (Sterio, 1984). This method involved examining two serial sections of known distance (h) apart. The number (Q-) of profiles that appeared in one section ('reference section') but not in an adjacent serial section ('look-up section') in a given area of tissue was determined. In this study, since consecutive serial sections were used as the test and look-up sections, the distance between sections (h) was equal to the section thickness (t). Each section in a given pair and for a given hippocampal regions was, in turn, examined under a light microscope fitted with a computer with Pro Plus image analyser. All images were captured and immediately stored in digital format in the computer and printed using a laser printer. A random sampling procedure was used to select fields of view for further analysis. The image of the field selected in a 'reference section' was captured and stored in computer. The corresponding field was then located in the consecutive 'look-up section' and its image again stored in computer. The CA1, CA2 and CA 3 of hippocampus were examined using a $\mathrm{x} 40$ objective magnification. The final magnification of the printed images was determined to be $x 1700$ in this study. The images of both 'reference' and 'look-up' sections were superimposed with a counting frame that was printed on a transparency (Fig. 3). The frame was made up of a length and width of continuous line (inclusion line) and an interrupted line (exclusion line). Size of frame used in this study was 159 x $80 \mathrm{~mm}$. The total area (a) in this frame was calculated to be $0.0044 \mathrm{~mm}^{2}$. Counts were made of the total number of neuronal nuclear profiles appearing in the micrographs from the 'reference section' but not appearing in the corresponding micrographs of the look-up sections. In order to increase efficiency, each micrograph was used, in turn, first as the reference section and then as the look-up section (Gundersen, 1986). All counting procedures were performed using the 'forbidden line' rule (Gundersen, 1977). According to this rule, any nuclear profile that appeared in the frame and inclusion line was counted whereas, any nuclear profile appearing in the exclusion line was not counted. Estimation of the numerical density of neurons $(\mathrm{Nv})$ in CA hippocampal region were obtained using the formula $\mathrm{Nv}=\Sigma \mathrm{Q}$-/ah, where ' $\mathrm{a}$ ' is the total area of the test section examined for that given region (Sterio, 1984).

Estimation of total number of pyramidal cells. The total number of pyramidal neurons in the CA1, CA2 and CA3 of any given hippocampus was estimated by multiplying the volume of the hippocampal region (as determined by the Cavalieri method) with the corresponding numerical density of neurons. 


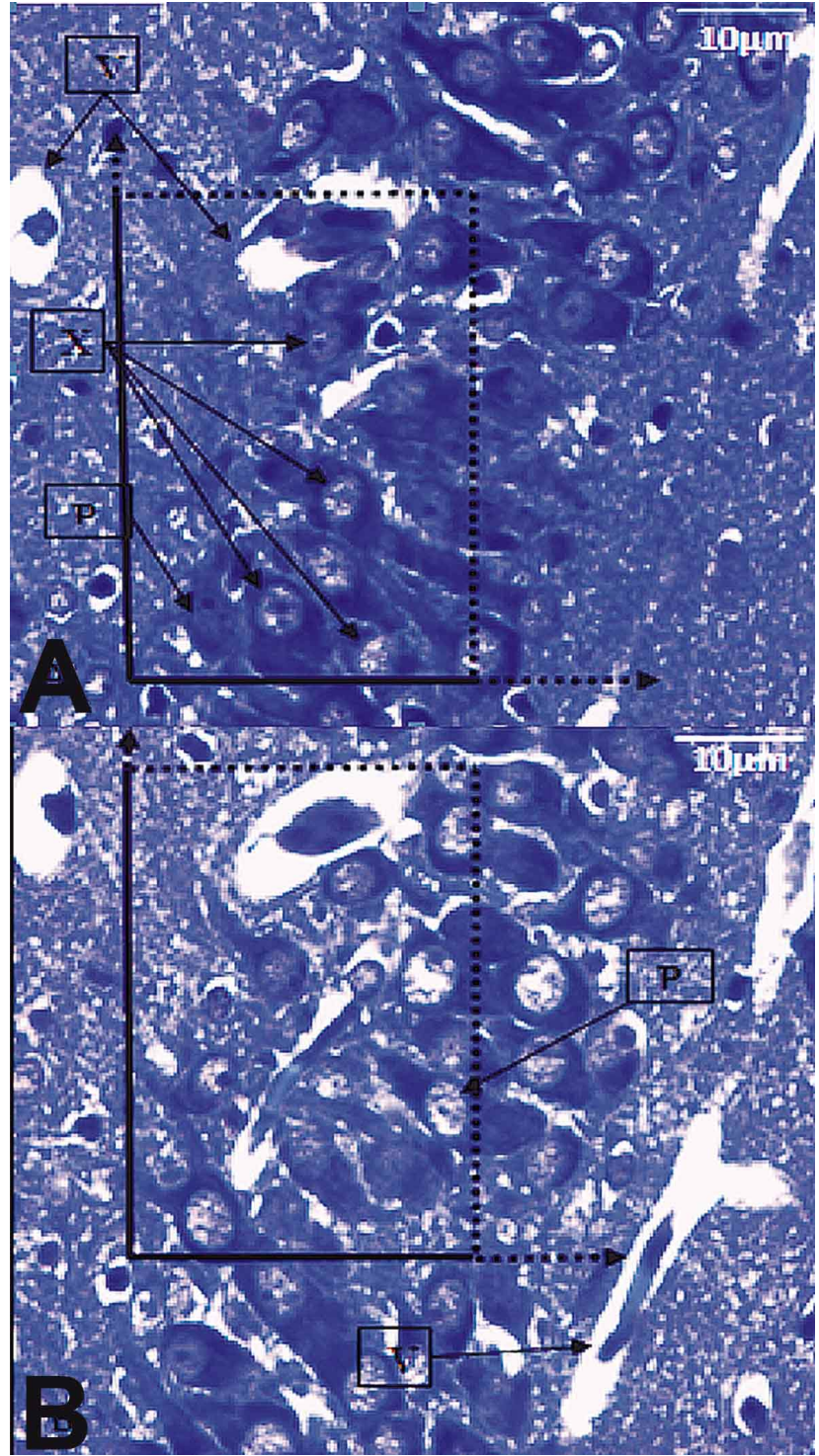

Fig. 3. Photo micrograph A and B show two consecutive $4 \mu \mathrm{m}$ thick section of hippocampal pyramidal cells layer in Toluidine blue staining. A is the first section of these two consecutive sections and referred to as the "reference section" and B is the consecutive section of A and referred as "look-up section". Both sections were superimposed with a rectangular frame which represents the counting frame. Any pyramidal cell $(\mathrm{P})$ which appear in "reference section" and not in "look-up section" were counted (X).

All methods and materials used in this study were approved by Animal Ethics Committee Universiti Sains Malaysia (AECUSM).

Statistical Analysis. Statistical analysis was performed by using Statistical Package for Social Sciences (SPSS) version 12 software on a DELL compatible computer. The normality of each variables data was evaluated. These were then analyzed appropriately using either one way analysis of variant (ANOVA) or Kruskal Wallis statistical test. One wayANOVA statistical test was applied to analyze the volume and numerical density of hippocampal pyramidal cell layer. $\mathrm{P}$-value of less than 0.05 was considered as significant at 95\% confidence interval. Kruskal Wallis statistical test was applied to analyze the total number of pyramidal cells in the hippocampal CA region. P-value of less than 0.05 was considered as significant at $95 \%$ confidence interval.

\section{RESULTS}

Representative photomicrographs from $4 \mu \mathrm{m}$-thick Toluidine blue stained section through $\mathrm{CA} 1+\mathrm{CA} 2+\mathrm{CA} 3$ region from the sham, treatment and control groups are shown in Figure 4. There were no obvious gross morphological or microscopic abnormalities seen in any of the hippocampal region examined. Mean volume of pyramidal cell layer of hippocampal CA region of the sham, treatment and control groups were $1.43 \mathrm{~mm}^{3}, 1.37 \mathrm{~mm}^{3}$ and $1.19 \mathrm{~mm}^{3}$ respectively (Fig. 5). One way ANOVA of these data showed no significant difference of pyramidal cells layer volume of hippocampal CA region between all groups $(\mathrm{F}=$ $2.415, \mathrm{p}>0.05$ ) (Table I).

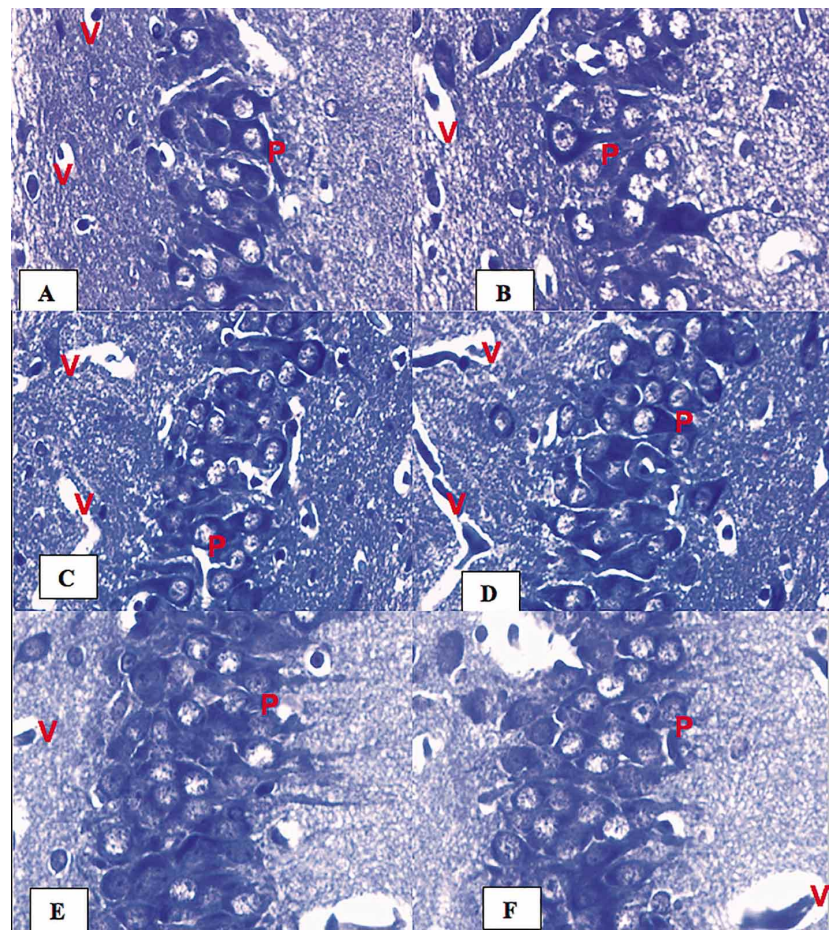

Fig. 4. Representative photomicrograph of $4 \mu \mathrm{m}$-thick Toluidine blue-stained sections of pyramidal layer of part of hippocampal CA region from the sham (A \& B), treatment (C \& D), and control $(\mathrm{E} \& \mathrm{~F})$ groups at $40 \mathrm{X}$ objective magnification. 'P' marks some of the pyramidal cells identified in the section and ' $\mathrm{V}$ ' shows blood vessels that are visible in the section. 
Table I. One way ANOVA results of pyramidal cells layer volume of hippocampal CA region.

\begin{tabular}{lccccc}
\hline \multirow{2}{*}{ Group } & \multirow{2}{*}{} & \multicolumn{2}{c}{ Volume $\left(\mathbf{m m}^{\mathbf{3}}\right)$} & \multirow{2}{*}{$\begin{array}{c}\text { F-statistic } \\
\text { (df) }\end{array}$} & $\begin{array}{c}\text { p- } \\
\text { value }\end{array}$ \\
\cline { 3 - 4 } Sham & 16 & 1.43 & 0.36 & & \\
Treatment & 16 & 1.37 & 0.38 & $2.42(2.45)$ & 0.101 \\
Control & 16 & 1.19 & 0.23 & & \\
\hline
\end{tabular}

* One-way ANOVA test1. P-value of $<0.05$ as significant at 95\% CI. 1Assumption were met: normality of distribution was normal and homogeneity of variance (Levene's test) was not significant ( $\mathrm{p}$-value $>0.05$ ).

Volume of pyramidal cell layer CA region of hippocampus

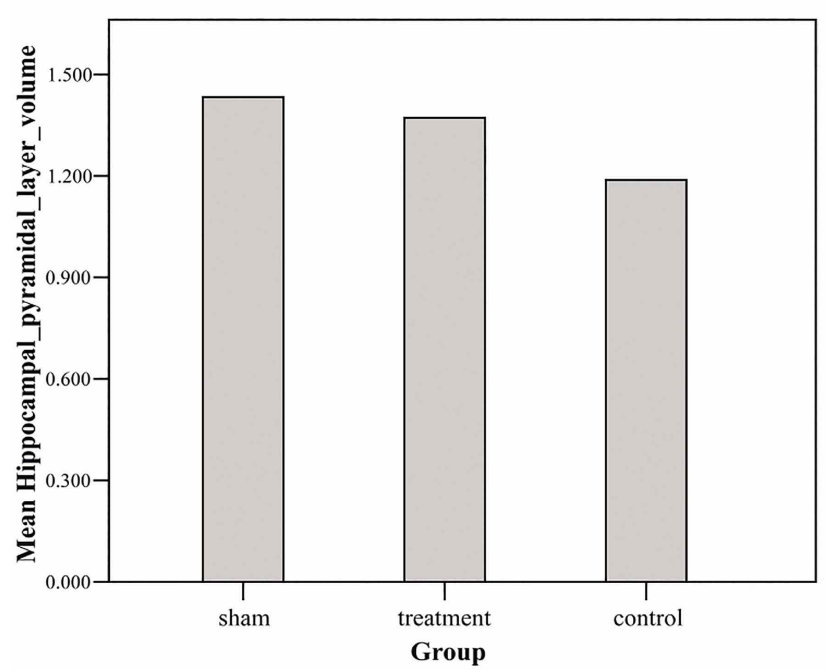

Fig. 5. Mean volume $\left(\mathrm{mm}^{3}\right)$ of pyramidal layer of hippocampal CA region.

Pyramidal cells density of hippocampal CA region

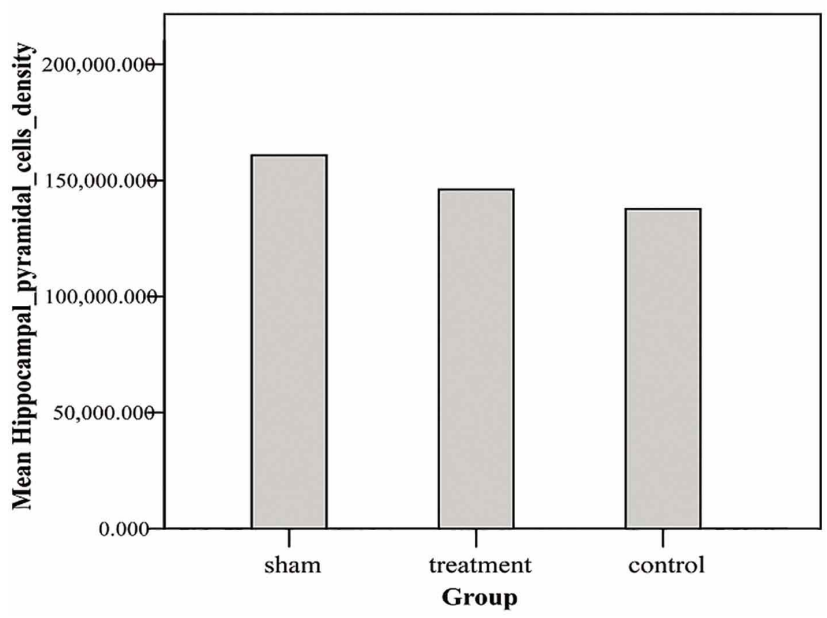

Fig. 6. Mean density of pyramidal cells $\left(\right.$ cells $/ \mathrm{mm}^{3}$ ) of hippocampal CA region.
Total pyramidal cells number of hippocampal CA region.

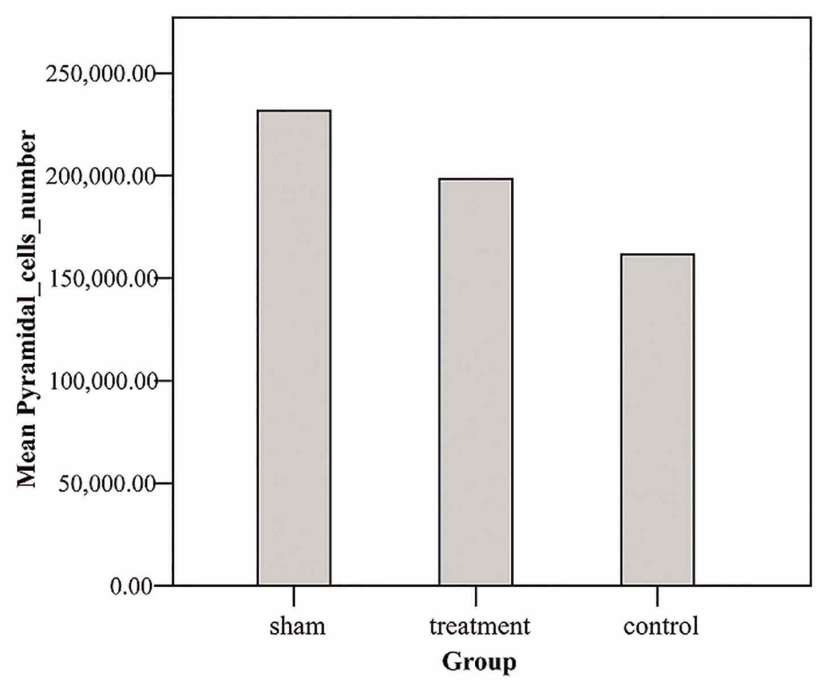

Fig. 7. Mean estimates of the total pyramidal cell number (cells/ hippocampus) of hippocampal CA region.

Figure 6, shows the mean numerical densities of pyramidal cells in the $\mathrm{CA} 1+\mathrm{CA} 2+\mathrm{CA} 3$ region from all groups in this study. Mean density of pyramidal cell of hippocampal CA region of the sham, treatment and control groups were 160839 cells $/ \mathrm{mm}^{3}, 146122$ cells $/ \mathrm{mm}^{3}$ and 137705 cells $/ \mathrm{mm}^{3}$ respectively. One way ANOVA of this data showed no significant different in numerical density of the examined region (Table II).

Figure 7 , shows the means of total number of pyramidal cells in the $\mathrm{CA} 1+\mathrm{CA} 2+\mathrm{CA} 3$ regions from all groups in this study. Mean total number of pyramidal cell of hippocampal CA region of the sham, treatment and control groups were 231626 cells, 198299 cells and 161505 cells respectively (Table III). The assumption for one way ANOVA had been violated because data is not normally distributed. Kruskal Wallis analysis of this data showed no significant difference in total number of pyramidal cells of the examined region (Table IV). It was shown that the mean of the pyramidal cells number in the progesterone treated pups were significantly higher compared to control group but lower when compared to sham group. 
KHAN, A. A.; RAMLI, N. B. \& ISMAIL, Z. M. The effects of progesterone on hypoxic ischemic injuries in the cornu ammonis (CA) region of the hippocampus of neonatal rats. Int. J. Morphol., 33(3):962-970, 2015.

Table II. One way ANOVA result of pyramidal cells density $\left(\right.$ cells $\left./ \mathrm{mm}^{3}\right)$ of CA1+CA2+CA3 region of hippocampus.

\begin{tabular}{|c|c|c|c|c|c|}
\hline \multirow[t]{2}{*}{ Group } & \multirow[t]{2}{*}{$\mathbf{n}$} & \multicolumn{2}{|c|}{$\begin{array}{l}\text { Numerical density } \\
\left(\text { cells } / \mathbf{m m}^{3}\right)\end{array}$} & \multirow{2}{*}{$\begin{array}{l}\text { F-statistic } \\
\text { (df) }\end{array}$} & \multirow[t]{2}{*}{ p-value ${ }^{*}$} \\
\hline & & Mean & SD & & \\
\hline Sham & 16 & 160839 & 69793 & & \\
\hline Treatment & 16 & 146122 & 48127 & $0.68(2.45)$ & 0.511 \\
\hline Control & 16 & 137705 & 49657 & & \\
\hline
\end{tabular}

* One-way ANOVA test1. P-value of $<0.05$ as significant at $95 \%$ CI. 1Assumption were met: normality of distribution was normal and homogeneity of variance (Levene's test) was not significant (p-value >0.05)

Table III. Descriptive data of total pyramidal cells number (cells/hippocampus) of $\mathrm{CA} 1+\mathrm{CA} 2+\mathrm{CA} 3$ region of hippocampus.

\begin{tabular}{lccc}
\hline \multirow{2}{*}{ Group } & & \multicolumn{2}{c}{$\begin{array}{c}\text { Total number of pyramidal cells in CA1+CA2+CA3 } \\
\text { hippocampal region (cells/region) }\end{array}$} \\
\cline { 3 - 4 } & $\mathbf{n}$ & Mean & SD \\
\hline Sham & 16 & 231626 & 122134 \\
Treatment & 16 & 198299 & 79343 \\
Control & 16 & 161505 & 61173 \\
\hline
\end{tabular}

Table IV. Kruskal Wallis test result of the total pyramidal cells number (cells/hippocampus) of CA1+CA2+CA3 region of hippocampus.

\begin{tabular}{|c|c|c|c|c|c|}
\hline \multirow[t]{2}{*}{ Variable } & \multicolumn{3}{|c|}{$\begin{array}{c}\text { Total number of pyramidal cells of } \\
\text { hippocampal CA region Median (IQR) }\end{array}$} & \multirow{2}{*}{$\begin{array}{c}\text { Chi square } \\
\text { (df) }\end{array}$} & \multirow{2}{*}{ p-value } \\
\hline & Sham & Treatment & Control & & \\
\hline $\begin{array}{l}\text { Total number of } \\
\text { pyramidal cells }\end{array}$ & $\begin{array}{c}193222 \\
(140824)\end{array}$ & $\begin{array}{r}169763 \\
(92871)\end{array}$ & $\begin{array}{l}154649 \\
(72865)\end{array}$ & $4.12(2)$ & 0.122 \\
\hline
\end{tabular}

\section{DISCUSSION}

Hypoxic ischemic model of brain injury in our present study was observed to be effective in producing some amount of brain tissue infarction. This experiment is also known as animal stroke model of brain injury. The unilateral common carotid artery ligation in the present study was aimed to simulate the focal cerebral ischemia. The main brain region affected by hypoxic ischemic model in this study was the ipsilateral part of forebrain including the cerebral cortex, subcortical and periventricular white matter, striatum (basal ganglia), and hippocampus (Vannucci \& Vannucci). Succeeding hypoxic ischemic insult, the neuronal damage occurs in two phases. First phase of cell death takes place immediately following the insult. In severe insult, it would cause immediate neuronal and glial death. The first phase of neuronal death is often referred as necrotic phase, which is an irreversible process of neuronal degeneration via random deoxyribonucleic acid (DNA) degeneration (Walker et al., 1988; Gluckman et al., 2001). Necrotic neuronal death is a predominant form of neuronal degeneration following severe hypoxic ischemic.

The second phase of cell death occurs within hours or days after initial insult. This delayed form of cell death is known as apoptosis or programmed cell death (Gluckman et al.; Northington et al., 2001). This process which involves energy produces a neuronal death by an ordered DNA degradation without stimulating massive immune response that could potentially destroy the surrounding cells (Gluckman et al.). Devoid of reperfusion after hypoxic ischemic insult however aggravates the energy depletion in the neuronal tissue in ongoing apoptotic process (Edwards et al., 1995). 
The trend of the outcomes observed in the present study was similar in all variables. The mean volume of pyramidal cell layer, the numerical density and the total number of pyramidal cells in the CA region of hippocampus were measured to be higher in the sham group, followed by the treatment group and lowest in the control group. Based on the trend, there could be minimal protection shown by progesterone. However, progesterone at a dose of $4 \mathrm{mg} / \mathrm{kg}$ was shown not to produce significant improvement in the total number of surviving pyramidal cells.

The probable mechanisms of minimal neuroprotection as observed in the present study might be similar as what have been postulated in adult rats. For instance, a significant preservation of selective vulnerable hippocampal neuronal population in CA1 and CA2 was found in the treatment group via activation of intracellular signaling pathway involved in the promotion of cell survival by expression of anti-apoptotic molecules such as Bcl-2 and Bcl-XL (Moralí et al.). It also prevents increment of pro-apoptotic molecule such as Bax, Bad and caspase-3 (Cai et al., 2008).

Progesterone also demonstrated the ability to produce GABAergic effects in the brain subsequently inhibits neuronal excitability and reduces neuronal damage (Jiang et al.). Progesterone inhibits neuronal excitability via potentiating gamma-aminobutyric acid (GABA)-evoked chloride currents and thus produces an anticonvulsant activity (Kokate et al., 1994).

Besides the molecular action to reduce apoptosis, progesterone was also proven to reduce cerebral edema of the brain. This would in turn reduce the intracranial pressure and subsequently prevent further damage of brain tissues. Raised intracranial pressure would induce neuronal damage by decreasing blood supply to the edematous brain, which would further exacerbate the ischemic event. The mechanism of how progesterone acts to attenuate edema is not fully understood (Shear et al.). Nevertheless, there are some interesting hypotheses suggested by researchers (Stein, 2008).

Progesterone also has been hypothesized to be a free radical scavenger via its action in reducing peroxidase damage (Betz \& Coester, 1990). This has probably been explained by the mechanism of how progesterone reduces edema via the protection of blood brain barrier from destructive activity of free radicals (Roof et al., 1996). Alternative actions of progesterone include modulation of function of neural microvascular endothelial cells and inhibition of active ion transports mediated by $\mathrm{Na}^{+} \mathrm{K}^{+}$ATPase. Progesterone restores neuronal membrane potential through stimulation of $\mathrm{Na}^{+} \mathrm{K}^{+}$ ATPase, increases ion transport and nutrient uptake and thus induces neuronal survival (Chen et al.). Another role of free radical scavenger of progesterone is to prevent mitochondrial injury that consequently preserve the energy production and attenuate neuronal damage (Robertson et al., 2006).

The sparing neuronal survival after progesterone treatment has been shown to be associated with improvement in cognitive and behavioral functions which are severely disrupted after cortical contusion (Roof et al., 1994). A wider window treatment is provided by progesterone when delayed administration of progesterone up to 24 hours post ischemic insult was also proven to be effective in reducing edema (Roof et al., 1996). This is in contrast to methylprednisolone for which administration must be initiated within 8 hours post injury to be effective (Braughler \& Hall, 1984). Another factor that could contribute to a reduction in cerebral edema after progesterone treatment is probably by suppression of an inflammatory cytokine, interleukin 1-beta (IL-1ß) which is the major cause for cerebral edema following traumatic brain injury (Gibson et al., 2005). This action restores blood brain barrier integrity and prevents cerebral edema (He et al., 2004).

A particular asset of progesterone is that it is not only provides neuroprotection but also promotes myelin formation either during development or during remyelination of axons in the adult peripheral and central nervous system (Schumacher et al., 2007). It is also interesting to note that three days after spinal cord transection, expression of myelin basic protein (MBP) at the mRNA and protein levels were restored to control levels by progesterone (Labombarda et al., 2002).

Clinical trial investigating the neuroprotective effect of progesterone in human traumatic brain injury was carried out in 100 trauma patients (Wright et al., 2007). It has been found that the progesterone treated patients had more than $50 \%$ lower mortality rate 30 days after the injury. Patient with moderate traumatic brain injury in treatment group had better functional outcomes, although there was no improvement on disability in severe traumatic brain injury. Most importantly, this study highlighted that there was no adverse event attributed to prolonged infusion of high doses of progesterone.

The dose and method of preparation and administration of progesterone used in the present study might be inadequate or inappropriate since the amount of significant protective dose and administration of progesterone in adult rats was observed to be different in various preparations. For example, administration of water soluble progesterone preparation via intravenous injection showed significant neuroprotective effects of progesterone at $8 \mathrm{mg} / \mathrm{kg}$ (Chen et al.; Moralí et $a l$.). In studies where progesterone was dissolved in dimethyl sulphoxide and administered via intraperitoneal injections, the significant dose was found to be at $4 \mathrm{mg} / \mathrm{kg}$ (Jiang et al.). 
In a different study, progesterone dissolved in corn oil and given via subcutaneous injection showed significant neuroprotective dose at $10 \mathrm{mg} / \mathrm{kg}$ (Cervantes et al., 2002). Therefore, there could be a possibility that the selected dose of progesterone in the current study might be inadequate, leading to a minimal or non-significant protection towards hypoxic ischemic neuronal injury.

\section{CONCLUSION}

In conclusion, progesterone at $4 \mathrm{mg} / \mathrm{kg}$ was shown to be minimally beneficial but not significantly protecting the pyramidal cells of hippocampal formation from dying after hypoxic ischemic injury in neonatal rats.

\section{ACKNOWLEDGEMENTS}

I am grateful to Universiti Sains Malaysia (USM) for funding this research through the short term Grant (304/PPSP/ 61310033). My sincere thanks to Dr. Asma Hassan, Head of the Department for giving me this opportunity to work on this topic. I am also thankful to technologist Mr. Mohd Harisal and Eidi Azhary for helping in carrying out this study.

KHAN, A. A.; RAMLI, N. B. \& ISMAIL, Z. M. Efectos de la progesterona en lesiones por hipoxia isquémica en la región cornu ammonis (CA) del hipocampo en ratas neonatas. Int. J. Morphol., 33(3):962-970, 2015.

RESUMEN: La hipoxia-isquémica (HI) es una causa importante de daño cerebral en el recién nacido. Varios estudios indican los efectos neuroprotectores de la progesterona en ratas adultas, sin embargo existe poca literatura disponible en ratas recién nacidas. Por tanto, el presente estudio se llevó a cabo para ver el efecto de la progesterona en la lesión cerebral HI en ratas recién nacidas, utilizando un modelo de cría de rata neonata HI establecido. A los siete días de nacidas, las crías de ratas fueron sometidas a la ligadura de la arteria carótida común derecha y luego 60 minutos de hipoxia. La primera dosis de progesterona fue administrada al grupo de tratamiento mediante inyección peritoneal $(4 \mathrm{mg} / \mathrm{kg})$, después de 10 minutos de exposición y las dosis posteriores fueron administradas por inyecciones subcutáneas en intervalos de 6 h, 24 h y 48 h. El grupo control también fue expuesto a HI y se le administró solamente aceite de cacahuete a través de la misma ruta y con los intervalos que recibió el grupo de tratamiento. Después de $96 \mathrm{~h}$, las crias fueron perfundidas con formalina al 10\% y se tomaron muestras de los cerebros, los que se tiñeron con azul de toluidina. La densidad celular y el número de células piramidales de las regiones del hipocampo Cornu Ammonis (CA) fueron examinadas por métodos estereológicos. La evaluación histomorfométrica de los efectos de la progesterona mostró un va- lor protector mínimo, pero no significativo en el volumen, densidad de las células y el número total de células piramidales de la región de CA del hipocampo de los grupos de tratamiento y control $(\mathrm{p}>0,05)$ después de HI. En conclusión, nuestros resultados indican que $4 \mathrm{mg} / \mathrm{kg}$ de progesterona no tuvo efecto neuroprotector significativo en el modelo de HI del hipocampo de ratas neonatas.

PALABRAS ClAVE: Cornu Ammonis; Hipocampo; Hipoxia; Isquemia; Ratas neonatas; Neuroprotector; Progesterona; Células piramidales.

\section{REFERENCES}

Betz, A. L. \& Coester, H. C. Effect of steroids on edema and sodium uptake of the brain during focal ischemia in rats. Stroke, 21(8):1199-204, 1990

Braughler, J. M. \& Hall, E. D. Effects of multi-dose methylprednisolone sodium succinate administration on injured cat spinal cord neurofilament degradation and energy metabolism. J. Neurosurg., 61(2):290-5, 1984.

Cai, J.; Kang, Z.; Liu, K.; Liu, W.; Li, R.; Zhang, J. H.; Luo, X. \& Sun, X. Neuroprotective effects of hydrogen saline in neonatal hypoxia-ischemia rat model. Brain Res., 1256:129-37, 2009.

Cai, W.; Zhu, Y.; Furuya; K.; Li, Z.; Sokabe, M. \& Chen, L. Two different molecular mechanisms underlying progesterone neuroprotection against ischemic brain damage. Neuropharmacology, 55(2):127-38, 2008.

Cervantes, M.; González-Vidal, M. D.; Ruelas, R.; Escobar, A. \& Moralí, G. Neuroprotective effects of progesterone on damage elicited by acute global cerebral ischemia in neurons of the caudate nucleus. Arch. Med. Res., 33(1):6-14, 2002.

Chen, J.; Chopp, M. \& Li, Y. Neuroprotective effects of progesterone after transient middle cerebral artery occlusion in rat. J. Neurol. Sci., 171(1):24-30, 1999.

Edwards, A. D.; Yue, X.; Squier, M. V.; Thoresen, M.; Cady, E. B.; Penrice, J.; Cooper, C. E.; Wyatt, J. S.; Reynolds, E. O. \& Mehmet, H. Specific inhibition of apoptosis after cerebral hypoxiaischaemia by moderate post-insult hypothermia. Biochem. Biophys. Res. Commun., 217(3):1193-9, 1995.

Gibson, C. L.; Jones, N. C.; Prior, M. J.; Bath, P. M. \& Murphy, S. P. G-CSF suppresses edema formation and reduces interleukin-1beta expression after cerebral ischemia in mice. J. Neuropathol. Exp. Neurol., 64(9):763-9, 2005.

Gluckman, P. D.; Pinal, C. S. \& Gunn, A. J. Hypoxic-ischemic brain injury in the newborn: pathophysiology and potential strategies for intervention. Semin. Neonatol., 6(2):109-20, 2001.

Gundersen, H. J. \& Jensen, E. B. The efficiency of systematic sampling in stereology and its prediction. J. Microsc., 147(Pt. 3):229-63, 1987. 
Gundersen, H. J. Stereology of arbitrary particles. A review of unbiased number and size estimators and the presentation of some new ones, in memory of William R. Thompson. J. Microsc., 143(Pt. 1):3-45, 1986.

Gundersen, H. J. Notes on the estimation of the numerical density of arbitrary profiles: the edge effect. J. Microsc., 111(2):219-23, 1977.

He, J.; Evans, C. O.; Hoffman, S. W.; Oyesiku, N. M. \& Stein, D. G. Progesterone and allopregnanolone reduce inflammatory cytokines after traumatic brain injury. Exp. Neurol., 189(2):404$12,2004$.

Jiang, N.; Chopp, M.; Stein, D. \& Feit, H. Progesterone is neuroprotective after transient middle cerebral artery occlusion in male rats. Brain Res., 735(1):101-7, 1996.

Kokate, T. G.; Svensson, B. E. \& Rogawski, M. A. Anticonvulsant activity of neurosteroids: correlation with gamma-aminobutyric acid-evoked chloride current potentiation. J. Pharmacol. Exp. Ther., 270(3):1223-9, 1994.

Labombarda, F.; Gonzalez, S. L.; Gonzalez, D. M.; Guennoun, R.; Schumacher, M. \& de Nicola, A. F. Cellular basis for progesterone neuroprotection in the injured spinal cord. J. Neurotrauma, 19(3):343-55, 2002.

Miki, T.; Harris, S. J.; Wilce, P.; Takeuchi, Y. \& Bedi, K. S. Neurons in the hilus region of the rat hippocampus are depleted in number by exposure to alcohol during early postnatal life. Hippocampus, 10(3):284-95, 2000a.

Miki, T.; Harris, S. J.; Wilce, P.; Takeuchi, Y. \& Bedi, K. S. A stereological analysis of the effect of early postnatal ethanol exposure on neuronal numbers in rat dentate gyrus. Image Anal. Stereol., 19:99-104, 2000b.

Moralí, G.; Letechipía-Vallejo, G.; López-Loeza, E.; Montes, P.; Hernández-Morales, L. \& Cervantes, M. Post-ischemic administration of progesterone in rats exerts neuroprotective effects on the hippocampus. Neurosci. Lett., 382(3):286-90, 2005.

Northington, F. J.; Ferriero, D. M.; Flock, D. L. \& Martin, L. J. Delayed neurodegeneration in neonatal rat thalamus after hypoxia-ischemia is apoptosis. J. Neurosci., 21(6):1931-8, 2001.

Robertson, C. L.; Puskar, A.; Hoffman, G. E.; Murphy, A. Z.; Saraswati, M. \& Fiskum, G. Physiologic progesterone reduces mitochondrial dysfunction and hippocampal cell loss after traumatic brain injury in female rats. Exp. Neurol., 197(1):235-43, 2006.

Roof, R. L.; Duvdevani, R.; Braswell, L. \& Stein, D. G. Progesterone facilitates cognitive recovery and reduces secondary neuronal loss caused by cortical contusion injury in male rats. Exp. Neurol., 129(1):64-9, 1994.

Roof, R. L.; Duvdevani, R.; Heyburn, J. W. \& Stein, D. G. Progesterone rapidly decreases brain edema: treatment delayed up to 24 hours is still effective. Exp. Neurol., 138 (2):246-51, 1996.
Sayeed, I.; Wali, B. \& Stein, D. G. Progesterone inhibits ischemic brain injury in a rat model of permanent middle cerebral artery occlusion. Restor. Neurol. Neurosci., 25(2):151-9, 2007.

Schumacher, M.; Guennoun, R.; Stein, D. G. \& De Nicola, A. F. Progesterone: therapeutic opportunities for neuroprotection and myelin repair. Pharmacol. Ther., 116(1):77-106, 2007.

Shear, D. A.; Galani, R.; Hoffman, S. W. \& Stein D. G. Progesterone protects against necrotic damage and behavioral abnormalities caused by traumatic brain injury. Exp. Neurol., 178(1):59-67, 2002.

Stein, D. G. Progesterone exerts neuroprotective effects after brain injury. Brain Res. Rev., 57(2):386-97, 2008.

Sterio, D. C. The unbiased estimation of number and sizes of arbitrary particles using the disector. J. Microsc., 134(Pt. 2):127-36, 1984.

Vannucci, R. C.; Connor, J. R.; Mauger, D. T.; Palmer, C.; Smith, M. B.; Towfighi, J. \& Vannucci, S. J. Rat model of perinatal hypoxicischemic brain damage. J. Neurosci. Res., 55(2):158-63, 1999.

Vannucci, R. C. \& Vannucci, S. .J. A model of perinatal hypoxicischemic brain damage. Ann. N. Y. Acad. Sci., 835:234-49, 1997.

Volpe, J. J. Neurology of the Newborn. 5th ed. Philadelphia, Saunders Elsevier, 2008.

Walker, N. I.; Harmon, B. V.; Gobé, G. C. \& Kerr, J. F. Patterns of cell death. Methods Achiev. Exp. Pathol., 13:18-54, 1988.

Wright, D. W.; Kellermann, A. L.; Hertzberg, V. S.; Clark, P. L.; Frankel, M.; Goldstein, F. C.; Salomone, J. P.; Dent, L. L.; Harris, O. A.; Ander, D. S.; Lowery, D. W.; Patel, M. M.; Denson, D. D.; Gordon, A. B.; Wald, M. M.; Gupta, S.; Hoffman, S. W. \& Stein, D. G. ProTECT: a randomized clinical trial of progesterone for acute traumatic brain injury. Ann. Emerg. Med., 49(4):391-402, 2007.

\section{Correspondence to:}

Aaijaz Ahmed Khan

Senior Lecturer, Department of Anatomy

Universiti Sains Malaysia

Kubang Kerian - 16150

Kelantan

MALAYSIA

Phone: 0060-9-7676554

Mobile: 0060179031662

Fax: 006097653370

Email ID: aaijazk@gmail.com, aaijaz@usm.my

Received: 03-12-2014

Accepted: 13-07-2015 